\title{
Radiological Status of Drinking Water Sources Around a Coal Mining Site in Kogi State, North Central Nigeria
}

\section{${ }^{1 *}$ MOMOH, AH; ${ }^{1}$ OCHALLA, I; ${ }^{1}$ OCHENI, DO; ${ }^{1}$ AJIBADE, DR; ${ }^{2}$ BELLO, AI}

\author{
${ }^{1}$ Department of Physics, Kogi State University, Anyigba Nigeria \\ ${ }^{2}$ Division of Agricultural Colleges, Ahmadu Bello University, Zaria, Nigeria \\ *Corresponding Author Email: adavizehameed@gmail.com
}

\begin{abstract}
The radioactivity of drinking water sources around Okaba coal mining area in Ankpa local government area of Kogi state, North central Nigeria have been carried out using a low background Gasless AlphaBeta Counting System (Protean Instrument Corporation) - MPC 2000DP. The gross alpha and gross beta activity of water samples from four (4) sources (river/stream, borehole, sachet water and rain water) was measured. The grossalpha and gross-beta activity concentrations recorded were below the safe limits of $0.5 \mathrm{~Bq} / 1$ and $1 \mathrm{~Bq} / 1$ respectively, as recommended by the world health organization (WHO, 2017). Also, results of the committed effective dose (for adult and infant) calculated were all below the reference dose level (RDL) of $0.1 \mathrm{mSv} / \mathrm{yr}$ (WHO, 2017) except for BW3 whose adult dose was above the RDL. Therefore, there is no immediate risk of internal radiation exposure to the populace via intake of water from the four major sources of drinking water around Okaba coal mining area However, caution should be taken especially with regards long-term consumption of the ground water (BW3).
\end{abstract}

\section{DOI: https://dx.doi.org/10.4314/jasem.v24i5.27}

Copyright: Copyright $(\subseteq 2020$ Momoh et al. This is an open access article distributed under the Creative Commons Attribution License (CCL), which permits unrestricted use, distribution, and reproduction in any medium, provided the original work is properly cited.

Dates: Received: 10 March 2020; Revised: 15 April 2020; Accepted: 24 May 2020

Keywords: Okaba, radioactivity, gross-alpha, gross-beta, coal, water

Coal, an organic rock in the earth's crust is mostly composed of carbon. It also contains elements like oxygen, hydrogen, nitrogen and sulfur, in addition to some inorganic elements and water. The mining of coal no doubt has brought mixed blessings to people around the world. It is used primarily for electric power generation with its attendant environmental and health effects to the populace. The major environmental impact of the coal industry which includes issues relating to land use, quality of water, waste management and air pollution has been a source of concern to governments, environmentalists, health practitioners, scientists and researchers all over the world. The mining of coal at Okaba in Ankpa local government area of Kogi state has adversely affected the environment, especially their drinking water. During the dry season the rivers in the area become reddish in colour due to the toxic substances released during coal mining and as such, the water becomes unhealthy for swimming, drinking, and other domestic purposes. Also, it has been observed that within the neighborhood where coal is mined, loud noise from the site and the tremors from the blasts greatly affect the populace. It was obvious to see cracked buildings, and we found out that glass wares and glass windows do suffer breakages due to the vibrations from the mining site. The main sources of drinking water available to Okaba dwellers are streams/river water, sachet water and rain water. A few residents equally have access to borehole water. Sadly, most consumers are careless of the quality of water they take. While It is wrong to judge water quality simply by looking, smelling, or tasting it as it may contain dissolved substances of disease-causing organisms (Borehole Water Journal, 2017), it remains the only means of water quality assessment available to the populace. Health concerns include the high amount of magnesium and nitrates in some borehole water (Borehole Water Journal, 2017), poor conditions of the rivers and reported water-borne diseases due to human activities (e.g. washing, bathing, stooling, domestic waste, mining wastes and sewage disposal etc.) and potential exposure to radiation due to Naturally Occurring Radioactive Materials (NORMs) and Technologically Enhanced NORMs. NORMs can be enhanced due to human activities like mining and industrial waste disposal into nearby rivers and streams. Therefore, the mining activities in Okaba village may affect the natural radioactivity of the water consumed by the populace. Since the community is already facing environmental challenges earlier mentioned above, they may as well be exposed to radiation due to enhanced NORMs. An investigation into the radiological status of the various drinking 
water sources will forestall the possibility of radiation exposure to the populace since the presence of radionuclides in the water poses a number of health hazards, especially when these radionuclides are deposited in the human body through drinking (Olanrewaju et al, 2018). Dissolved radionuclides in water can emit particles ( $\alpha$ and $\beta$ ) and $\gamma$-rays (photons) and these can cause genetic problems, cancer and even death (Gruber, et al, 2009). Ra-226, Th-232 and K-40 (in solid or liquid samples) remain the key contributor radionuclides responsible for human exposures and differ from region to region. Therefore, the knowledge of their distribution in coal, soil and water will assist in radiation measurement and protection activities since radionuclides concentrations above permissible levels can be very detrimental to human health. The most current reference dose level set by world health organization (WHO, 2017) for gross alpha activity in drinking water is $0.5 \mathrm{~Bq} / \mathrm{L}$ and that for gross beta activity in drinking water is $1.0 \mathrm{~Bq} / \mathrm{L}$. Also, the reference dose level for total effective dose for both adult and infant is $0.1 \mathrm{mSv} / \mathrm{yr}$. So, the aim of this research work is to investigate the gross alpha and gross beta activity in drinking water sources around Okaba mining area and also to find effective and total effective doses due to one year's consumption by adults and infants.

\section{MATERIALS AND METHODS}

Study Area: The study area (Fig. 1) is Okaba district in Ankpa local government area of Kogi state, North Central Nigeria. Okaba, a rural coal mining community, has a geographic coordinates of $7^{\circ} 23^{\prime} 0^{\prime} ' \mathrm{~N}$ and $7^{\circ} 44^{\prime} 0^{\prime}$ ' $\mathrm{E}$. The coal mine itself is located in Odagbo, with a population above 3500 people living on the outskirts of Okaba. Okaba districts lies some $16 \mathrm{Km}$ North-East of Ankpa town and is within the tropical hinterland with a total annual rainfall range between $100-200 \mathrm{~cm}$ (Omale et al, 2017). Observations and records show that Okaba has a clayey soil, which is quite muddy and difficult to walk through in wet seasons. The inhabitants are mainly Igala-speaking people, who have lived a sedentary lifestyle for years, engaged in farming arable crops and rearing livestock. Accessing clean potable water for domestic use and growing livestock is a major challenge the inhabitants face. It's a common scene to see untreated mining waste expelled from mining sites into nearby streams which serve as a source of drinking water to the people and their animals.

Sample Collection and Preparation: A total of ten (10) water samples were randomly collected from the available drinking water sources in Okaba community. Samples were taken from three rivers/streams and three boreholes. Three rain water samples was also collected including water from a well-known sachet water factory for analysis.

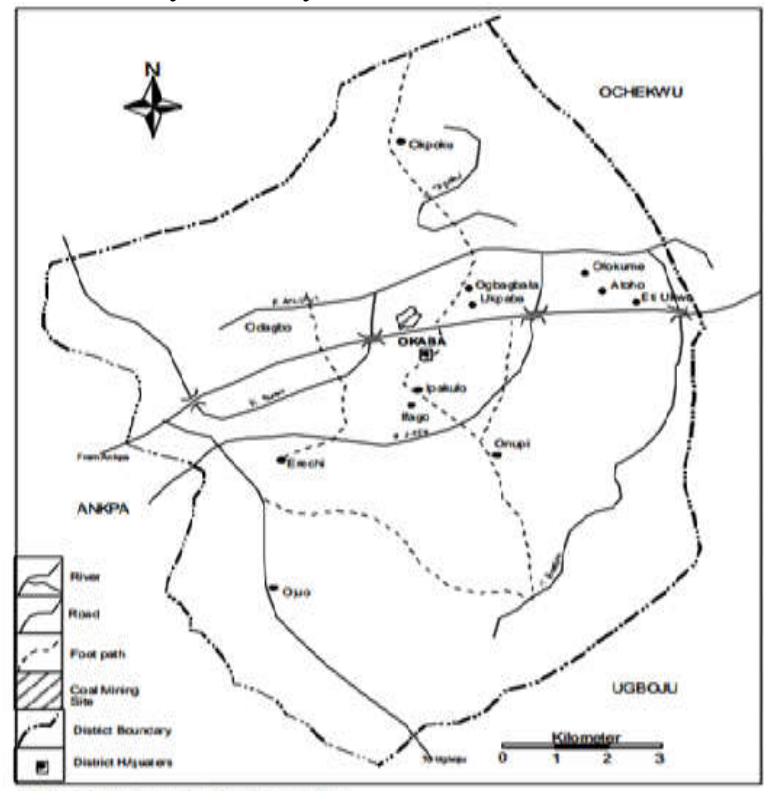

Souree: Ministry of land and Survoy Lokoin

Fig 1: Map of Okaba in Ankpa Local Government Area of Kogi State - Nigeria

The location of the sampling points was taken with a portable Global Positioning System (GPS) tool. A two (2) litre container was used to collect each sample after thoroughly rinsing them with the water sample to be collected. The containers were not filled to the brim; little space was left for thermal expansion. The river/stream water samples were collected very early in the morning from the communities' regular points of fetching water using the grab sampling technique (Avwiri and Agbalaba, 2007).

The bore-hole water was allowed to run with pressure through the taps for a few minutes before it was collected into the containers. This helped to purge the plumbing system (Tchokossa et al., 1999). Also, clean containers were placed outside in the rain to collect rain water samples directly from the sky. This helped to minimize any contamination through roofing sheets, tanks, buckets, etc. that are traditionally used in the collection process of rain water. Finally, the sachet water sample was gotten from a famous sachet water factory in the area. All samples collected were immediately acidified with nitric acid $\left(\mathrm{HNO}_{3}\right)$ to check unwanted growth of microorganisms and to avert precipitation and absorption of the sample by the walls of the container. They were properly sealed in their various containers and subsequently conveyed to the low background laboratory of the Center for Energy Research and Training (CERT), Ahmadu Bello University, Zaria. 
Sample Analysis: The water samples were put in an open beaker, and placed on an electric hotplate to undergo a gradual evaporation process. It took about 30 hours to complete the process for a 2 litre sample. When the level of the sample in the beaker was about $50 \mathrm{ml}$, it was transferred into a petri dish and subsequently placed under an infrared source to ensure a complete dryness of the residue. The samples were subsequently left to cool down, weighed using a laboratory scale and later placed in the low background Gasless Alpha-Beta Counting System (Protean Instrument Corporation) - MPC 2000DP, to determine the alpha and beta activity concentrations. The MPC 2000DP alpha-beta counter uses a solid state silicon (Passivated Implanted Planar Silicon - PIPS) detector to detect alpha and beta particles. Having counted the samples for 200 minutes (Bello et al., 2018), the alpha and beta efficiencies was gotten to be $87.95 \%$ and $42.06 \%$ respectively. The background reading of the alpha and beta activity concentration were $0.33 \mathrm{cpm}$ and $0.27 \mathrm{cpm}$ respectively and the detection limit for alpha activity was $0.21 \mathrm{cpm}$ while that of beta activity was $0.22 \mathrm{cpm}$. The calibration sources used were $\mathrm{Sr}-90$, a beta source and $\mathrm{Pu}-239$ which is an alpha source.

Gross Alpha Counting: The alpha count rate was calculated using the formula below; according to ISO, 1992.

$$
\text { Count rate }(\alpha)=\frac{\text { Raw } \alpha \text { count }}{\text { Count time }}
$$

The alpha activity concentration was calculated using the formula below; according ISO, 1992:

Activity $(\alpha)=\frac{\operatorname{CR}(\alpha)-B C(\alpha)}{\mathrm{DF} \times \mathrm{SV} \times \mathrm{SF}} \times 0.0167$

Where $\mathrm{CR}=$ count rate; $\mathrm{BC}=$ background count; $\mathrm{DF}$ $=$ Detection efficiency, $\mathrm{SV}=$ sample volume and $\mathrm{SF}=$ sample efficiency

Gross Beta Counting: The beta count rate was calculated using the formula below; according to ISO, 1992.

Count rate $(\beta)=\frac{\text { Raw } \beta \text { count }}{\text { Count time }}$

The beta activity concentration was calculated using the formula below; according to ISO, 1992:

Activity $(\beta)=\frac{\mathrm{CR}(\beta)-B C(\beta \beta)}{\mathrm{DF} \times \mathrm{SV} \times \mathrm{SF}} \times 0.0167$

Committed Effective Dose: Ingestion and inhalation of radionuclides are possible ways they reach the internal organs of the body where they cause serious damages especially the alpha and beta particles that have very high ionizing power. The annual alpha and beta effective dose due to intake of the various water sources around Okaba coal mining site was found via the mean of the individual annual committed effective doses contributed by the major alpha and beta emitters in the Uranium - 238 and Thorium - 232 series of the naturally occurring radioactive materials (NORMs), according to Ogundare and Adekoya (2015). The following formulae were used to find the effective dose over one year of consumption of water (IAEA, 2003):

$$
\begin{aligned}
& E_{\text {avg }}(\alpha \text { or } \beta)=\sum A_{i(\alpha \text { or } \beta)} X D C F_{i(\alpha o r \beta)} \times 730 \text { (Adult) } \\
& E_{\text {avg }}(\alpha \text { or } \beta)=\sum A_{i(\alpha \text { or } \beta)} X D C F_{i(\alpha o r \beta)} \times 183 \text { (Infant) }
\end{aligned}
$$

Where $E_{\text {avg }}(\alpha$ or $\beta)$ is the average gross annual alpha or beta committed effective dose in drinkable water, $\mathrm{A}_{\mathrm{i}}(\alpha$ or $\beta)$ is the gross alpha or beta activity concentration of individual radionuclide present in the water samples and DCF $\mathrm{i}(\alpha$ or $\beta)$ is the dose conversion factor in $\mathrm{Sv} / \mathrm{Bq}$ for ingestion of the individual radionuclide, it was assumed based on EPA (2005) report that an adult consumes a minimum of 2 liters of water per day resulting in an annual consumption rate of 730 liters per year while an infant consumes $1 / 2$ liter of water per day resulting in an annual consumption rate of 183 liters per year. It was also assumed based on the report from Damlah et al. (2006) that more than $50 \%$ of the annual dose from intake of water corresponds to radium (gross alpha radium). This assumption was necessary since the proportional counter could not determine the radionuclide elements present in the water samples due to its limited function.

Gortir et al. (2011), reported that Radium - 226 contributes mainly to gross alpha activities while Lead - 210 and Radium - 228 contribute majorly to beta activities. For calculations, according to WHO (2004), the dose conversion factor of $2.8 \times 10^{-4} \mathrm{~Sv} / \mathrm{Bq}$ is used for Radium -226 and $6.9 \times 10^{-4} \mathrm{~Sv} / \mathrm{Bq}$ for both Lead -210 and Radium -228.

Statistical Analysis: Microsoft Excel was used for the analysis.

\section{RESULTS AND DISCUSSION}

Radioactivity of drinking water sources around Okaba coal mining area has been carried out. The gross alpha and gross beta activity concentrations in river, borehole, sachet water, and rain water samples are 
shown in Table 1 above. The gross alpha activity concentration ranges from $0.0018 \pm 0.0018 \mathrm{~Bq} / 1$ to $0.1377 \pm 0.0102 \mathrm{~Bq} / 1$ with a mean value of $0.0306 \pm$ $0.0027 \mathrm{~Bq} / \mathrm{L}$. Also, the gross beta activity concentrations ranges from $0.0134 \pm 0.0022 \mathrm{~Bq} / 1$ to $0.4032 \pm 0.0219 \mathrm{~Bq} / 1$ with a mean value of $0.08279 \pm$ $0.0057 \mathrm{~Bq} / \mathrm{L}$. BW3 recorded the highest gross alpha activity concentration while RW2 recorded the lowest concentration. The highest gross beta activity concentration was recorded in BW3 and the lowest activity recorded in RIV1. BW3 recorded the highest gross alpha and beta activities probably due to its close proximity to the mining area compared to other sampling points. All results recorded for gross alpha and gross beta activity concentrations were below the reference dose level (RDL) of $0.5 \mathrm{~Bq} / 1$ and $1.0 \mathrm{~Bq} / \mathrm{l}$ respectively as set by world health organization (WHO, 2017). Figure 2 shows the gross alpha and beta activity concentrations. Table 2 below shows the effective dose and the total effective equivalent dose to adults and infants, due to gross alpha and gross beta activity.

Table 1: Activity concentration of water samples around Okaba coal mining area.

\begin{tabular}{|c|c|c|c|c|c|c|}
\hline \multirow[t]{2}{*}{$\mathrm{S} / \mathrm{N}$} & \multirow{2}{*}{$\begin{array}{l}\text { Sample } \\
\text { Codes }\end{array}$} & \multirow[t]{2}{*}{ Description } & \multicolumn{2}{|c|}{ Geographical Coordinates } & \multicolumn{2}{|c|}{ Sample Gross Radioactivity Measurement } \\
\hline & & & Longitude & Latitude & Alpha Activity $(\mathrm{Bq} / \mathrm{L})$ & Beta Activity $(\mathrm{Bq} / \mathrm{L})$ \\
\hline 1 & RIV1 & Stream/River & $\mathrm{N} 7^{0} 27^{\prime} 29.9^{\prime \prime}$ & $\mathrm{E} 7^{0} 44^{\prime} 11.2^{\prime \prime}$ & $0.0138 \pm 0.0013$ & $0.0134 \pm 0.0022$ \\
\hline 2 & RIV2 & Stream/River & $\mathrm{N} 7^{0} 28^{\prime} 4.4^{\prime \prime}$ & E7 ${ }^{0} 44^{\prime} 19.3^{\prime \prime}$ & $0.0088 \pm 0.0031$ & $0.0185 \pm 0.0058$ \\
\hline 3 & RIV3 & Stream/River & $\mathrm{N} 7^{0} 28^{\prime} 29.4^{\prime \prime}$ & E7 $7^{0} 44^{\prime} 18.9^{\prime \prime}$ & $0.0203 \pm 0.0029$ & $0.0922 \pm 0.0064$ \\
\hline 4 & RW1 & Rain & $\mathrm{N} 7^{0} 28^{\prime} 26.8^{\prime \prime}$ & $\mathrm{E} 7^{0} 43^{\prime} 14.5^{\prime \prime}$ & $0.0109 \pm 0.0005$ & $0.0230 \pm 0.0011$ \\
\hline 5 & RW2 & Rain & $\mathrm{N} 7^{0} 28^{\prime} 26.4^{\prime \prime}$ & $\mathrm{E} 7^{0} 43^{\prime} 16.4^{\prime \prime}$ & $0.0018 \pm 0.0018$ & $0.0251 \pm 0.0038$ \\
\hline 6 & RW3 & Rain & $\mathrm{N} 7^{0} 28^{\prime} 25.8^{\prime \prime}$ & $\mathrm{E} 7^{0} 43^{\prime} 16.0^{\prime \prime}$ & $0.0727 \pm 0.0044$ & $0.1521 \pm 0.0086$ \\
\hline 7 & BW1 & Borehole & $\mathrm{N} 7^{0} 28^{\prime} 30.5^{\prime \prime}$ & $\mathrm{E} 7^{0} 43^{\prime} 18.4^{\prime \prime}$ & $0.0283 \pm 0.0023$ & $0.0675 \pm 0.0046$ \\
\hline 8 & BW2 & Borehole & $\mathrm{N} 7^{0} 28^{\prime} 25.5^{\prime \prime}$ & $\mathrm{E} 7^{0} 43^{\prime} 22.3^{\prime \prime}$ & $0.0076 \pm 0.0008$ & $0.0192 \pm 0.0016$ \\
\hline 9 & BW3 & Borehole & $\mathrm{N} 7^{0} 28^{\prime} 34.1^{\prime \prime}$ & $\mathrm{E} 7^{0} 43^{\prime} 20.8^{\prime \prime}$ & $0.1377 \pm 0.0102$ & $0.4032 \pm 0.0219$ \\
\hline \multirow[t]{2}{*}{10} & SW1 & Sachet water & $\mathrm{N} 7^{0} 28^{\prime} 27.5^{\prime \prime}$ & E7043'15.9' & $0.0044 \pm 0.0006$ & $0.0137 \pm 0.0012$ \\
\hline & & & & Mean Activity & $0.0306 \pm 0.0027$ & $0.0828 \pm 0.0057$ \\
\hline & & 0.45 & & & & \\
\hline & & 0.4 & & & & \\
\hline & & 0.35 & Gross Alpha & & & \\
\hline & & Ð 0.3 & Gross Beta & & & \\
\hline & & $\stackrel{\infty}{\cong} 0.25$ & & & & \\
\hline & & 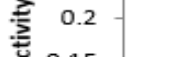 & & & & \\
\hline & & 0.1 & & & & \\
\hline & & 0.05 & & & & \\
\hline & & & RIV3 & RW1 & BW1 BW2 & sw1 \\
\hline
\end{tabular}

Fig 2: Gross alpha and beta activity of drinking water sources around Okaba mining area

Table 2: Effective Dose and Total Effective Equivalent Dose to Adult and Infant

\begin{tabular}{|c|c|c|c|c|c|c|c|}
\hline & & $\begin{array}{l}\text { Alpha } \\
\text { Particle }\end{array}$ & $\begin{array}{l}\text { Beta } \\
\text { Particle }\end{array}$ & & $\begin{array}{l}\text { Alpha } \\
\text { Particle }\end{array}$ & $\begin{array}{l}\text { Beta } \\
\text { Particle }\end{array}$ & \\
\hline $\begin{array}{l}\mathrm{S} / \\
\mathrm{N}\end{array}$ & Sample & $\begin{array}{l}\text { Eff Dose } \\
\text { (mSv/yr)- } \\
\text { Adult }\end{array}$ & $\begin{array}{l}\text { Eff Dose } \\
\text { (mSv/yr)- } \\
\text { Adult }\end{array}$ & $\begin{array}{l}\text { Total Eff Dose } \\
\text { (mSv/yr)- } \\
\text { Adult }\end{array}$ & $\begin{array}{l}\text { Eff Dose } \\
\text { (mSv/yr)- } \\
\text { Infant }\end{array}$ & $\begin{array}{l}\text { Eff Dose } \\
\text { (mSv/yr)- } \\
\text { Infant }\end{array}$ & $\begin{array}{l}\text { Total Eff Dose } \\
\text { (mSv/yr)- } \\
\text { Infant }\end{array}$ \\
\hline 1 & RIV1 & $2.8207 \mathrm{E}-03$ & $6.7496 \mathrm{E}-03$ & $9.5703 \mathrm{E}-03$ & 7.0711E-04 & $1.6920 \mathrm{E}-03$ & $2.3991 \mathrm{E}-03$ \\
\hline 2 & RIV2 & $1.7987 \mathrm{E}-03$ & $9.3185 \mathrm{E}-03$ & $1.1117 \mathrm{E}-02$ & $4.5091 \mathrm{E}-04$ & $2.3360 \mathrm{E}-03$ & $2.7869 \mathrm{E}-03$ \\
\hline 3 & RIV3 & $4.1493 \mathrm{E}-03$ & 4.6441E-02 & $5.0590 \mathrm{E}-02$ & $1.0402 \mathrm{E}-03$ & $1.1642 \mathrm{E}-02$ & $1.2682 \mathrm{E}-02$ \\
\hline 4 & RW1 & $2.2280 \mathrm{E}-03$ & $1.1585 \mathrm{E}-02$ & $1.3813 \mathrm{E}-02$ & $5.5852 \mathrm{E}-04$ & $2.9042 \mathrm{E}-03$ & $3.4627 \mathrm{E}-03$ \\
\hline 5 & RW2 & $3.6792 \mathrm{E}-04$ & $1.2643 \mathrm{E}-02$ & $1.3011 \mathrm{E}-02$ & $9.2232 \mathrm{E}-05$ & $3.1694 \mathrm{E}-03$ & $3.2616 \mathrm{E}-03$ \\
\hline 6 & RW3 & $1.4860 \mathrm{E}-02$ & 7.6613E-02 & $9.1473 \mathrm{E}-02$ & $3.7251 \mathrm{E}-03$ & $1.9206 \mathrm{E}-02$ & $2.2931 \mathrm{E}-02$ \\
\hline 7 & BW1 & $5.7845 \mathrm{E}-03$ & $3.4000 \mathrm{E}-02$ & $3.9784 \mathrm{E}-02$ & $1.4501 \mathrm{E}-03$ & $8.5232 \mathrm{E}-03$ & $9.9733 \mathrm{E}-03$ \\
\hline 8 & BW2 & $1.5534 \mathrm{E}-03$ & $9.6710 \mathrm{E}-03$ & $1.1224 \mathrm{E}-02$ & $3.8942 \mathrm{E}-04$ & $2.4244 \mathrm{E}-03$ & $2.8138 \mathrm{E}-03$ \\
\hline 9 & BW3 & $2.8146 \mathrm{E}-02$ & 2.0309E-01 & $2.3124 \mathrm{E}-01$ & 7.0557E-03 & $5.0912 \mathrm{E}-02$ & $5.7968 \mathrm{E}-02$ \\
\hline 10 & SW1 & $8.9936 \mathrm{E}-04$ & $6.9007 \mathrm{E}-03$ & 7.8001E-03 & $2.2546 \mathrm{E}-04$ & $1.7299 \mathrm{E}-03$ & $1.9554 \mathrm{E}-03$ \\
\hline
\end{tabular}

The effective equivalent dose for adult ranges from 7.8 $\mathrm{x} 10^{-03} \mathrm{mSv} / \mathrm{yr}$ to $2.31 \times 10^{-01} \mathrm{mSv} / \mathrm{yr}$ with a mean value of $4.80 \times 10^{-02} \mathrm{mSv} / \mathrm{yr}$, while that of infants ranges from $1.96 \times 10^{-03} \mathrm{mSv} / \mathrm{yr}$ to $5.80 \times 10^{-02} \mathrm{mSv} / \mathrm{yr}$ with a mean of $1.20 \times 10^{-02} \mathrm{mSv} / \mathrm{yr}$. The highest values for both adults and infant was 
recorded in BW3. This may be due to high amount of beta emitting radionuclides like Lead -210 and Radium - 228 that have over the years percolated into ground water. However, the lowest value was recorded in the sachet water sample SW1. This may be due to the various water treatment procedures undertaken by the sachet water company to make their product healthy and acceptable to consumers. The recommended reference dose level (RDL) for committed effective dose (for adult and infant) is 0.1 $\mathrm{mSv}$ for one year consumption of drinkable water (i.e $0.1 \mathrm{mSv} / \mathrm{yr}$ ). Results from this study show that only sample BW3 exceeded the reference dose level for adult (See figure 3).

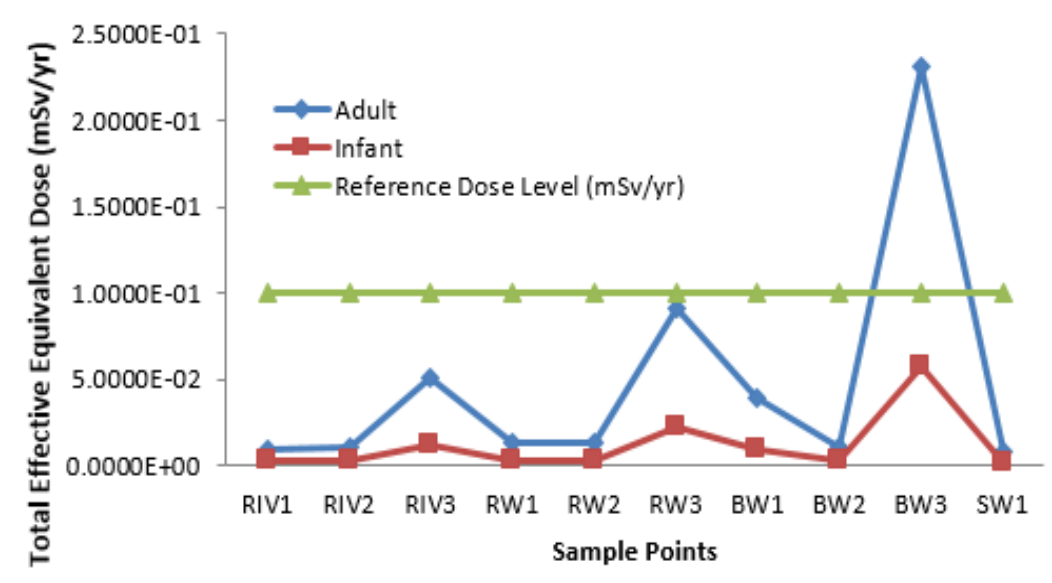

Fig 3: Total Effective Equivalent Dose for Adult and Infant with Reference Dose Level (RDL)

Conclusion: The radioactivity of drinking water sources around Okaba coal mining area have been carried out. The study reveals that gross alpha and gross beta activity concentrations of four (4) drinking water sources were below the safe limits of $0.5 \mathrm{~Bq} / 1$ and $1 \mathrm{~Bq} / 1$ respectively, as recommended by the world health organization. Also, results of the committed effective dose calculated were all below the reference dose level (RDL) of $0.1 \mathrm{mSv} / \mathrm{yr}$ except for BW3. So, caution should be taken concerning the consumption of ground water BW3 (borehole water).

\section{REFERENCES}

Avwiri, G O; Agbalagba, E O (2007). Survey of gross alpha and gross beta radionuclide activity in Okpare Creek, Delta state Nigeria. J. Appl. Sci. 7(22): $3542-3546$.

Bello, I A; Zakari, Y I; Garba, N N; Vatsa, A M; Kure, N. (2018), Radioactivity level in water around a cement factory in north central Nigeria. Sci. World J. 13 (1): 1597-6343.

Bore hole water journal (2019). www.bwa.co.za Accessed in 2019.

Damla, N; Cevik, U; Karahan, G; Kobya, A I (2006). Gross alpha and beta activities in tap water in eastern black sea region of Turkey. Chemosphere, 62(37), $957-960$.
Gortir , F K; Keser, R; Akcay, N; As, N; and Dizman, $\mathrm{S}$ (2011). Annual effective dose and concentration levels of gross alpha and beta in Turkish market tea. Iran J. of Rad. Res., 10(2), 67-72.

Gruber, V; Maringer F J; Landstetter, C (2009). Radon and other natural radionuclides in drinking water in Austria: measurement and assessment. App. Rad. and Isotopes, 67(5), 913-917.

International Atomic Energy Agency- IAEA (2003). International Basic Safety Standards for Protection against Ionizing Radiation and for the Safety of Radiation Sources, No. 115 (IAEA, Vienna,)

International Organization for Standardization- ISO (1992). Water quality measurement for gross alpha and beta activity in non-saline water, thick Source Method, ISO (9696 -1992 revised) and ISO (9697 -1992 revised). Geneva, Switzerland. $1992 ; 13$.

Ogundare F O; Adekoya O I (2015). Gross alpha and beta radioactivity in surface soil and drinkable water around a steel processing facility. J. of Rad. Res. and App. Sci. p $411-417$.

Olarenwaju A I; Osarulobe E; Avwiri G O (2018). Measurement of gross alpha and beta radioactivity in surface soil, mineral rock and consumable water around mining sites in Benue 
state, Nig. J. of Sci. Res. and Rep. vol. 18(5), P114.

Omale P E; Ibrahim B M; Okeniyi S O; Ngokat A B; Babarinde A O (2017). Radiological Assessment of Coal Samples from Selected Coal Mines in Nigeria, Chem. Res. J. 2(3): 22-28

Tchokossa, P; Olomo, J B; Osibota, O A (1999). Radioactivity in the community water supplies of Ife-central and Ife East L.G.A of Osun State, Nigeria. Nucl. Instr. Meth. Phys. Res. A422, 780 -784 .
United States Environmental Protection Agency (USEPA) (2000-05). Chapter 3: Exposure Scenarion Selection' http://www.epa.gov/earth1r6/6pd/rcra_c/pdo/chap3.pdf. Dallas, Tx.

World Health Organisation -WHO (2017). Guidelines for drinking-water quality: Fourth Edition incorporating the first addendum, Switzerland, 203-217. 